\title{
KAJIAN VISUAL KARAKTER DESAIN WEBTOON BE A POEM
}

\author{
Aninditya Daniar \\ Desain Komunikasi Visual, Pengkajian dan Penciptaan Seni \\ Pascasarjana Institut Seni Indonesia, Yogyakarta \\ Email: anindityadaniar@gmail.com
}

Diterima : 16 Juli 2020. Disetujui : $2 \underline{5}$ November 2020. Dipublikasikan : 1 Desember 2020
$\begin{aligned} & \text { (c) (7) } \\ & \text { (c) } 202 \underline{0} \text { - DESKOVI Universitas Maarif Hasyim Latif. Ini adalah artikel dengan akses }\end{aligned}$

\begin{abstract}
ABSTRAK
Komik web sekarang muncul sebagai salah satu komik konvensional yang banyak diminati oleh kalangan muda saat ini. Komik web dianggap lebih cocok untuk generasi masa kini yang lebih melirik pada produk dan pelayanan praktis secara online. Penelitian ini membahas tentang visual desain karakter bernama Poem pada komik web yang berjudul Be a Poem karya Chill Peeps. Karakter utama dalam webtoon tersebut berbentuk binatang sehingga memiliki keunikan karakter dan cerita yang digemari oleh banyak pembacanya. Desain karakter tersebut dianalisis dengan metode kualitatif berdasarkan unsur-unsur grafisnya yaitu gaya ilustrasi, layout, dan warna. Hasil dari analisis adalah desain karakter memiliki ciri khas masing-masing dalam gaya ilustrasi dan cerita yang khas sehingga mampu menarik perhatian pembaca muda. Berdasarkan studi kasus yang dilakukan maka dapat disimpulkan bahwa karakter desainer dapat memutar balikkan persepsi pembaca dengan menambah atau mengurangi atribut visual.
\end{abstract}

Kata kunci: desain Karakter, komik, webtoon, komik web, semiotika

\begin{abstract}
Webcomics now appear as one of the conventional comics that are in great demand by young people today. Webcomics are considered more suitable for today's generation who are more interested in online practical products and services. This study discusses the visual design of a character named Poem in a webcomic entitled Be a Poem by Chill Peeps. The main characters in the webtoon are in the form of animals that they have unique characters and stories that are loved by many readers. The character designs were analyzed by qualitative methods based on the graphic elements, namely illustration style, layout, and color. The results of the analysis are the character designs have their respective characteristics in the style of illustrations and unique stories so as to attract the attention of young readers. Based on the case studies, it can be concluded that the character of the designer can distort the reader's perception by adding or subtracting visual attributes.
\end{abstract}

Keywords: character design, comics, webtoon, web comics, semiotic

\section{PENDAHULUAN}

Karakter desain merupakan salah satu komunikasi penggambaran untuk mengkomunikasikan sebuah sikap atau image tertentu kepada orang lain. Dalam tulisan Ernawati 2019, daya sensitifitas setiap perupa atau kreator sebagai pencipta karya dalam merespon situasi lingkungan memiliki perbedaan, yang disampaikan melalui proses kreatif dengan bukti wujud berupa karya visual. Sehubungan dengan hal tersebut, kreator dalam mewujudkan gambar tekait dengan sebuah imajinasi yang kita miliki tentang berbagai hal yang menurut kita menarik. Menurut Tony White, karakter desain merupakan sebuah penggambaran kepribadian dan sifat-sifat emosional dari sebuah individu. Istilah karakter desain seringkali dikaitkan dengan original character serta mascot. Penggunaan karakter desain saat ini telah banyak diterapkan di berbagai bidang, seperti animasi, industri perfilman, game, mainan anak-anak, hingga mascot yang mewakili citra dari suatu perusahaan bahkan sebuah kota. Penggunaan karakter desain di Ingris juga dimanfaatkan sebagai sebuah mascot tim olahraga, yang tidak hanya sebagai gambar ilustrasi atau logo, namun juga diaplikasikan kedalam sebuah kostum, sehingga mascot tersebut dapat berinteraksi kepada orang yang melihatnya. Sedangkan di Jepang, karakter desain dibuat untuk merepresentasikan sebuah daerah yang kemudian menjadi sebuah brand ambassador dari wilayah tersebut, tidak hanya berhenti disitu, mascot tersebut juga diaplikasikan kedalam berbagai merchandise yang kemudian menjadi sumber 
pemasukan tersendiri bagi masyarakat yang tinggal disekitar wilayah tersebut.

Hello Kitty merupakan salah satu karakter desain yang diperuntukkan sebagai objek dekoratif. Hello kitty yang memiliki nama lengkap Kitti White adalah personifikasi dari kucing berwarna putih dengan ciri khas pita atau hiasan lainnya di daun telinga sebelah kiri dan mulut yang tidak digambar. Hello Kitty mampu menyampaikan cerita melalui illustrasi yang muncul pada setiap produknya. Pada tahun 2004 penjualan merchandise karakter desain Hello Kitty telah mencapai lebih dari \$1.000.000.000, wajah Hello Kitty saat ini terdapat pada lebih dari 70.000 produk, yang didistribusikan pada lebih dari 60 negara di seluruh dunia (Steward, 2004).

Karakter desain fenomenal lainnya adalah Snoopy. Berbeda dengan karakter Hello kitty yang didesain sebagai objek dekoratif, Snoopy merupakan salah satu desain karakter berupa anjing jenis beagle peliharaan Charlie Brown dalam strip komik Peanuts karya Charles M. Schulz yang digunakan sebagai maskot keselamatan oleh NASA.

Selain Hello kitty dan Snoopy masih banyak karakter desain lain yang digunakan berbagai instansi untuk mencapai tujuan mereka, seperti stickers untuk chating hingga ke bentuk promosi. Karakter desain yang baik adalah sebuah karakter desain yang disusun berdasarkan tujuan serta dapat mengakomodasi tercapainya sebuah tujuan tertentu, maka dari itu perancangan sebuah karakter desain harus melalui tahapan yang baik, mulai dari research, proses perancangan, hingga ke tahap eksesuki atau produksi (White, 2006). Dalam penelitian berikut juga akan dijelaskan salah satu metodologi perancangan komik web sebagai salah satu metode perancangan karakter desain dalam mencipta karakter desain.

Karakter Poem dalam komik web Be a Poem berbentuk binatang rakun berwarna kuning yang menjelajahi dunia fantasi untuk menolong seorang pangeran kucing kembali ke kerajaannya. Keunikan penggambaran karakter tersebut dirasa sangat unik serta cukup popular digunakan oleh seorang karakter desainer dalam menghasilkan sebuah original characters (OCs), dengan menggunakan karakter utama dari Be a Poem sebagai studi kasus, akan dicoba untuk menjabarkan latar belakang kombinasi serta efeknya terdahap persepsi penonton terhadap sebuah karakter yang dihasilkan.

Fokus utama pembahasan dalam penelitian berikut adalah untuk memaparkan tahapan atau proses yang digunakan dalam mendesain sebuah karakter desain yang sesuai dengan tujuan yang akan dihasilkan, dimana sebuah karakter desain yang baik adalah bukan hanya sebuah karakter desain yang memiliki tampilan menarik, namun juga mampu mengakomodasi kebutuhan serta mampu mengkomunikasikan ideologi dari institusi yang diwakilinya.

\section{METODE PENELITIAN}

Metode analisis yang digunakan dalam membedah karakter desain Poem merupakan gabungan dari interpretasi secara visual maupun secara kepribadian. Dalam tahap analisis visual, peneliti mengelompokkan berbagai unsur visual yang nampak pada karakter desain Poem, seperti: bentuk fisik, pakaian yang digunakan, serta warna yang digunakan. Tahap kedua yang dilakukan dalam menganalisis karakter tersebut adalah berdasarkan aspek kepribadian, pola pikir, serta gerak-gerik yang ditampilkan oleh seorang karakter desain kepada audiensnya. Kedua kategori tersebut dikembangkan berdasarkan Qualities of Characters Design yang dipublikasikan oleh Tony White dalam bukunya yang berjudul From Pencils to Pixels. Analisis selanjutnya adalah dengan menggunakan interpretasi makna dimana dalam interpretasi makna dikemukakan bahwa setiap unsur dalam desain memiliki pesan tersendiri yang ingin disampaikan, maka dari itu dengan menganalisis berbagai unsur yang terdapat pada karakter desain Poem berdasarkan persepsi visual secara psikologi maupun relasinya.

\section{HASIL DAN PEMBAHASAN}

Analisis karakter Poem. Poem merupakan karakter utama dari Webtoon Be a Poem, ia merupakan seekor rakun yang suka dengan tantangan. Poem adalah seorang berandalan di suatu daerah bernama The HUT. Pekerjaan Poem adalah adventure yang menerima bayaran dari misi-misi khusus. Sebelum Poem menjadi seorang adventure.

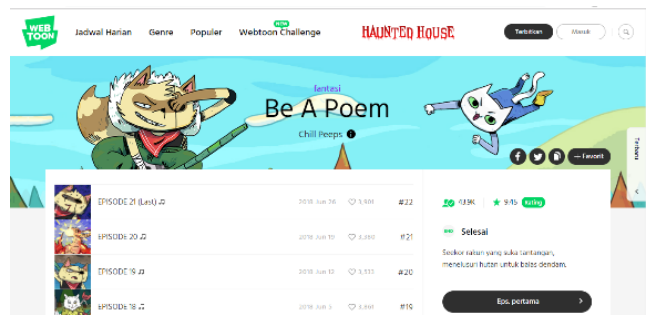

Gambar 1. Be a Poem

\section{Shape}

Secara bentuk terlihat bahwa karakter tersebut memiliki tubuh binatang rakun yang hidup, karakter tersebut memiliki bulu yang lebat dan dapat berdiri menggunakan dua kaki. Dalam penampilannya, ia terlihat menggunakan baju sederhana dan mengenakan mantel bulu. Karakter tersebut juga menggunakan asesories penutup mata dan perban di tangan, hal tersebut membuat kesan garang serta mengintimidasi musuh - musuh yang berhadapan dengannya. 


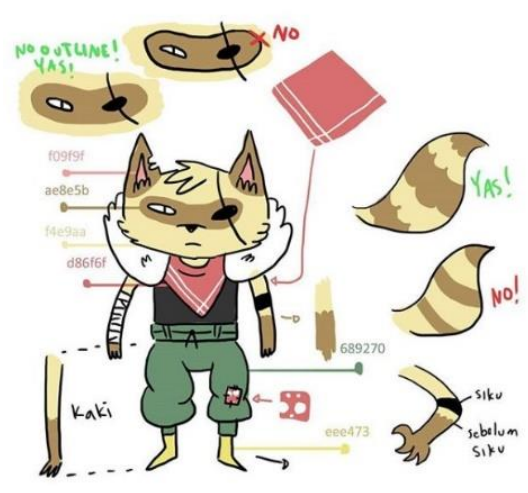

Gambar 2. Poem

Dalam metode pengurangan dijelaskan bahwa sebuah karakter desain dianalisis serta diteliti bagian bagian atau poin yang dinilai memiliki kualitas yang kurang menarik dan tidak terlalu penting. Elemen yang kurang penting diminimalisir untuk dapat menonjolkan elemen lain yang lebih penting. Dalam kasus karakter Poem tersebut adalah untuk menonjolkan kesan garang serta intimidasi oleh seekor rubah, maka wujud fisik secara rubah yang ramah dikurangi, namun dengan berkurangnya wujud fisik tersebut justru meningkatkan kesan garang yang dimiliki pada karakter tersebut. Dengan mengurangi bagian yang tidak terlalu penting tersebut mengakibatkan sosok karakter tersebut terlihat sangat berkarakter, unik, serta memiliki kesan yang kuat.

\section{Personality}

Secara kepribadian, karakter tersebut dapat digambarkan sebagai sebuah karakter yang cukup jeli dalam bertarung, selain itu ia juga karakter yang sangat berhati-hati dalam menentukan langkah yang akan diambilnya, sehingga segala keputusan yang diambilnya tidak akan menimbulkan permasalahan. Pada dasarnya personaliti Poem adalah seorang rakun remaja, namun seiring dengan semakin lamanya ia menjelajah, ia merasakan adanya perubahan dalam dirinya, khususnya dalam merasakan perasaan peduli dan melindungi hal yang berharga untuknya.

Sebagai satu-satunya penolong yang tersisa untuk melindungi pangeran kucing, ia sering menginga. Dilatar belakangi oleh rasa hormat kepada temantemannya yang telah lama menghilang dan meninggalkan kerajaan, Poem memperlakukan temannya dengan penuh rasa hormat dan tanggung jawab, bahkan ia cenderung sangat berhati-hati ketika ingin memberikan sebuah perintah tertentu kepada bawahannya. Sebagai karakter utama ia juga berusaha sangat keras dalam berprilaku selayaknya seorang yang dapat diandalkan, meskipun beberapa kali tidak jarang kejadian-kejadian konyol masih sering terjadi.

Bagi pangeran kucing, Poem merupakan seorang tokoh seorang kakak yang sangat rasional, yang membuat sebuah keputusan dengan sangat hatihati, Selain itu Poem merupakan karakter yang dinilai memiliki pemikiran terbuka, mampu menerima sebuah kritik, belajar dari kesalahan yang pernah dibuat, serta membimbing bawahannya dengan penuh kasih sayang. Secara garis besar, seluruh langkah yang dilakukan oleh Poem merupakan perilaku untuk kemajuan kerajaan para binatang. ia gemar mencari informasi terkait dunia luar, Pem tidak terlalu membenci musuhmusuhnya, namun ia tidak ragu untuk membunuh musuh yang menghalangi niatnya.

Disisi lain, Poem merupakan tokoh yang kompetitif, hal tersebut terlihat dari ketertarikannya pada hal-hal baru yang belum pernah ia ketahui sebelumnya. Misalkan, berdebat dengan teman lamannya, untuk mengetahui informasi tersebut Poem rela berpetualang untuk menyelamatkan pangeran kucing. Berbagai petualangan serta pencarian atas informasi tersebut juga dilatar belakangi oleh rasa ingin melindungi pangeran kucing, agar hal serupa tidak pernah terulang lagi.

\section{Colour}

Dalam analisis warna yang digunakan pada karakter Poem, terlihat dominasi warna kuning dan hitam pada warna bulu dan bajunya, warna merah dan hijau sebagai kombinasi warna utama pada pakaian yang dikenakan. Karakter Poem merupakan karakter jenis binatang rakun yang memiliki persepsi seram, Rakun sering kali dikonotasikan sebagai binatang licik yang sering menipu manusia (mahluk hidup). Sebagai karakter berjenis binatang rakun serta keahliannya dalam menggunakan kekuatan, warna-warna yang digunakan tentu mendukung dari citra yang ingin ditonjolkan dari karakter tersebut.

Berdasarkan Color Affects system, warna hitam melambangkan sebuah kecanggihan, pesona, aman, kestabilan emosi, efisien, serta subtansi. Warna hitam juga melambangkan penindasan, dingin, ancaman, serta beban. Warna hitam merupakan warna yang menyerap seluruh warna lainnya, secara psikologi warna hitam memiliki implikasi yang cukup besar, warna hitam membangun sebuah benteng tidak terlihat, warna hitam menyerap seluruh kepribadian, warna hitam mengkomunikasikan sesuatu dengan jujur, tanpa keraguan. Warna hitam merupakan warna yang cukup baik dikombinasikan dengan warna putih, ia mengkomunikasikan sesuatu yang unggul tanpa kompromi. Warna hitam dapat menimbulkan kesan serius dan berwibawa, warna hitam mumcul karena tidak ada pantulan cahaya, oleh karena sebagian besar manusia takut akan gelap, maka warna hitam juga dapat menimbulkan kesan ancaman (Wright, 2004).

Sedangkan wana kuning melambangkan kesan kehangatan, rasa berbahagia, kesenangan, serta gemar bermain. Secara Psikologis, makna kuning terasosiasi pada hasrat yang bersemangat, ceria, dan optimis. Untuk rasa dan emosi, warna kuning bisa menimbulkan kebahagiaan, terbuka (ekstrovert), supel, dan menarik perhatian. Warna kuning ini sering digunakan pada objek utama.

Warna merah memiliki asosiasi kontekstual yang berbeda dan didalam branding dapat 
menyampaikan pesan yang terlihat. Merah memiliki kemampuan untuk rev desire; dan tidak mengagetkan ketika merah adalah warna dari api, bahaya dan darah pada satu sisi; dan cinta, seksualitas, gairah pada sisi yang lain. Merah itu tebal, berenergi, dan warna yang hidup yang menyimbolkan kekuatan, kepercayaan diri dan kekuatan.

Warna hijau memiliki dua arti umum yang cukup paradoksal. pertama sebagai alam dan lingkungan, dan yang kedua sebagai keuangan dan kekayaan. Jika dihubungkan dengan alam, hijau mewakili tanaman hidup dan petumbuhan dan secara berkesinambungan digunakan untuk mempromosikan warna hijau pada lingkungan, kesinambungan, organik, esensi alami dari kata. Dan tentu saja warna hijau juga disangkut-pautkan dengan warna uang (uang Amerika Serikat) dan inilah kenapa dihubungkan dengan kekayaan dan stabilitas.

\section{PENUTUP}

Kesimpulan yang didapatkan setelah analisis yang dilakukan pada setiap unsur visual maupun personaliti pada karakter desain Poem merupakan kombinasi yang saling memperkuat kepribadian serta mampu membangun korelasi antara kepribadian serta tampilan. Tidak seperti persepsi umum tentang karakter rubah yang identik dengan karakter licik, karakter Poem mampu merepresentasikan persepsi sebagai tokoh kuat, tentunya dengan dukungan penggunaan atribut lain seperti adanya berbagai item yang dikenakan. Dengan adanya korelasi antara kepribadian serta unsur visual pada karakter tersebut membuat penonton menjadi lebih mudah untuk menerima informasi (kesan garang, kuat, lincah) yang ditampilkan.

\section{DAFTAR PUSTAKA}

Ernawati, E. (2019). ANALISIS TANDA PADA KARYA DESAIN KOMUNIKASI VISUAL. DESKOVI: Art and Design Journal, 2(1), 2734.

Fogelstrom, Elise. 2013. Investigation of Shape and Colours as Elements of Characters Design. UPPSALA Universitet.

Kress, G. \& van Leeuwen. T. 2006. Reading Images : the Grammar of Visual Design (second ed), London and New York : Routledge.

Pickens, Amy. 2005. Character Design With Variety and Purpose. southern methodist university.

Sobur, Alex. 2003. Semiotika Komunikasi. Bandung: PT. Remaja Rosdakarya.

Tsukamoto, Hiroyoshi. 2012. Super Manga Matrix. Harper Design.

Widagdo. 2011. Desain dan Kebudayaan. Bandung: Institut Teknologi Bandung.

White, Tony. 2006. ANIMATION: From Pencil to Pixels, Classical Techniques for Digital Animators. UK: Oxford. 